\title{
PEMENUHAN HAK ANAK SEBAGAI KORBAN TINDAKAN ASUSILA DALAM PERSPEKTIF HAM DI DESA TENGANAN-KARANGASEM
}

\author{
Yunita Resignata ${ }^{(1)}$ \\ Yunita Resignata12@gmail.com ${ }^{(1)}$ \\ Universitas Pendidikan Nasional
}

\begin{abstract}
Immoral acts are acts of crime that can occur anywhere and happen to anyone, except for minors who are supposed to be at the age of the child to get protection of growth and development in the family and also the environment in which they live. The impact caused by the act of immorality is the right of the child including the right to get protection is not fulfilled. Therefore the main purpose and focus of writing this journal is to find out and study the fulfillment of children's rights that are not fulfilled due to immoral acts. The research used in making this journal is an empirical research that emphasizes more on the investigation of behavioral aspects in this case community behavior. The research method used is a descriptive qualitative method, in this study the composer obtained legal material consisting of primary legal material and secondary legal material. Legal material collection techniques used are interview techniques and documentation techniques. However, the role of all levels of society is needed in terms of fulfilling children's rights as a nation's generation that needs to be protected. Protection of minors is very important so it must be applied both in the home, school and community environment because crime can come anytime and from anywhere so that protection becomes the main effective way to prevent crime from happening again.
\end{abstract}

Keywords: Fulfillment of Child Rights, Asusila Actions, Human Rights.

\begin{abstract}
ABSTRAK
Tindakan asusila merupakan tindakan kejahatan yang dapat terjadi dimana saja dan menimpa siapa saja tidak terkecuali terhadap anak di bawah umur yang seharusnya diumur tersebut anak mendapatkan perlindungan tumbuh dan kembangnya di keluarga dan juga lingkungan tempat tinggalnya. Dampak yang ditimbulkan dengan adanya tindakan asusila tersebut yaitu hak dari pada anak tersebut di antaranya hak untuk mendapatkan perlindungan tidak terpenuhi. Maka dari itu tujuan dan fokus utama penulisan jurnal ini yaitu untuk mengetahui dan mengkaji pemenuhan hak anak yang tidak terpenuhi akibat adanya tindakan asusila. Penelitian yang digunakan dalam pembuatan jurnal ini merupakan penelitian empiris yaitu lebih menekankan pada penyelidikan aspek perilaku dalam hal ini perilaku masyarakat. Metode penelitian yang digunakan adalah metode deskriptif kualitatif, dalam penelitian ini penyusun memperoleh bahan hukum yang terdiri dari bahan hukum primer dan bahan hukum sekunder. Teknik pengumpulan bahan hukum yang digunakan adalah teknik wawancara dan teknik dokumentasi. Akan tetapi diperlukan peranan seluruh lapisan masyarakat dalam hal pemenuhan hak-hak anak sebagai generasi bangsa yang perlu dilindungi. Perlindungan terhadap anak di bawah umur sangatlah penting sehingga harus diterapkan baik di dalam rumah, sekolah maupun lingkungan bermasyarakat karena kejahatan bisa datang kapan saja dan dari mana saja sehingga perlindungan menjadi cara utama yang ampuh mencegah kejahatan terjadi kembali.
\end{abstract}




\section{Kata Kunci: Pemenuhan Hak Anak, Tindakan Asusila, Hak Asasi Manusia.}

\section{PENDAHULUAN}

Berbicara mengenai anak tidak akan terlepas dari kejahatan yang kian marak mengintai anak sebagai korban dari kejahatan ini sendiri. Di Indonesia salah satu kejahatan yang menjadi sorotan adalah tindakan asusila yang dapat terjadi dimana saja dan menimpa siapa saja tidak terkecuali terhadap anak-anak yang seharusnya dilindungi. Tindakan asusila berkaitan dengan kejahatan seksual meliputi perkosaan, pencabulan, penyiksaan seksual, pelecehan seksual, perbudakan seksual, eksploitasi seksual, pemaksaan kehamilan dan yang lainnya adalah perilaku yang tidak sesuai dengan aturan norma-norma atau kaidah-kaidah kesopanan yang berlaku di masyarakat kemudian menjadi cerminan betapa lemahnya penegakan hukum di Indonesia selama ini. Kejahatan Seksual yang kian marak terjadi kemudian menimbulkan keresahan di dalam lingkungan masyarakat terkhusus bagi para orang tua yang memiliki anak laki-laki maupun anak perempuan yang sekarang semakin rentan menjadi target pelecehan seksual yang mana berdampak sangat buruk bagi anak ${ }^{1}$.

Anak-anak yang menjadi korban tindakan asusila seperti pencabulan, pemerkosaan, penyiksaan seksual dan yang lainnya merupakan anak yang mengemban pendidikan dan menjadi cikal bakal penerus bangsa yang seharusnya di lindungi. Dampak negatif yang sangat dirasakan dari maraknya kasus ini adalah semakin meningkatnya angka anak yang putus sekolah dan juga berdampak buruk bagi masa depan anak bangsa. Tidak hanya itu dampak lain dari kasus ini adalah anak yang menjadi korban kemudian hamil di usia yang masih tergolong muda sangat berdampak buruk dan mengkhawatirkan. Berbicara tentang kejahatan yang menjadikan anak sebagai korban maka perlu adanya peraturan yang mengatur mengenai perlindungan anak. Negara berkewajiban untuk memberikan perlindungan hukum terhadap seluruh warga masyarakat tanpa membedakan, seperti halnya memberikan perlindungan hukum bagi anak yang menjadi korban kejahatan yang marak terjadi. Perlindungan hukum bagi anak korban kejahatan kesusilaan dapat mencakup bentuk

1 Erlinda, M.Pd.,2014, Upaya Peningkatan Anak dari Bahaya Kekerasan, Pelecehan dan Eksploitasi, Komisi Perlindungan Anak Indonesia, h.13. 
perlindungan yang bersifat abstrak (tidak langsung) maupun yang konkret (langsung), karena dalam sistem peradilan di Indonesia ada asas equality before the law, terhadap semua warga negara yang hidup berdasarkan ketentuan Peraturan Perundang-undangan yang berlaku². Upaya pemenuhan hak dan perlindungan anak dapat dikatakan belum maksimal seperti halnya perlindungan dari tindakan asusila berkaitan dengan kejahatan seksual yaitu pencabulan yang melibatkan anak sebagai korban kembali terjadi seperti di desa Tenganan Pegringsingan, Karangasem. Desa Tenganan Pegringsingan ini terletak di Kecamatan Manggis, Kabupaten Karangasem di sebelah timur pulau Bali. Desa Tenganan merupakan salah satu desa yang masih mempertahankan pola hidup yang tata masyarakatnya mengacu pada aturan tradisional adat desa yang diwariskan nenek moyang mereka. ${ }^{3}$ Desa Tenganan ini sendiri memiliki luas wilayah 9,52 km² dengan jumlah penduduk di tahun 2016 mencapai 4.627 jiwa yang terbagi menjadi 2.248 laki-laki dan 2.379 perempuan. Keseharian kehidupan di desa ini masih diatur oleh hukum adat yang disebut awig-awig. Masyarakat desa Tenganan menganut sistem Endogami dalam perkawinan atau yang ingin melaksanakan perkawinan diwajibkan untuk memilih pasangan hidup yang berasal dari wilayah desa atau sukunya sendiri dan juga terdapat beberapa syarat dalam proses pekawinan yang apabila dilanggar akan mengakibatkan masyarakat yang melanggar ini dikenakan sanksi adat. Di desa Tenganan ini sendiri bagi anak yang melakukan tindakan asusila seperti tindakan pencabulan akan di kenakan sanksi adat yang mana perbuatan mereka telah melanggar aturan yang ada di desa ini dan sebagai sanksi, pihak orang tua dari anak ini juga akan di kenakan sanksi berupa denda seribu rupiah per tahun seumur hidup, karena dalam konteks ini yang salah menurut masyarakat adalah orang tua dalam mendidik anaknya maka sanksi moral lah yang masyarakat terapkan. Setiap perbuatan pidana sudah semestinya mendapatkan sanksi yang setimpal, sebagai pemenuhan dari asas yang berlaku yaitu asas Pertanggungjawaban Pidana yang mengandung makna bahwa setiap orang yang melakukan tindak pidana atau melawan hukum,

2 Abdul Wahid dan Muhammad Irfan, 2001, Perlindungan Terhadap Korban Kekerasan (advokasiatas hak asasi perempuan), Rafika Aditama, Bandung,h.78.

3 Amy Wirabudi, 2010,Terpikat Dobel Ikat: Tenun Gringsing,EVE MAGAZINE Indonesia. h. 89 
sebagaimana dirumuskan dalam undang-undang, maka orang tersebut patut mempertanggungjawabkan perbuatan sesuai dengan kesalahannya. Apabila di kaitkan dengan permasalahn di Desa Tengana tindakan asusila yang terjadi tidan hanya bias diselesaikan dan dengan sanksi adat yang berlaku tetap harus juga melalui hkum nasional yang berlaku agar hak dari pada korban tetap terpenuhi. Dengan kata lain orang yang melakukan perbuatan pidana akan mempertanggungjawabkan perbuatan tersebut dengan pidana apabila ia mempunyai kesalahan, seseorang mempunyai kesalahan apabila pada waktu melakukan perbuatan dilihat dari segi masyarakat menunjukan pandangan normatif mengenai kesalahan yang telah dilakukan orang tersebut ${ }^{4}$. Sehingga setiap orang yang melakukan kesalahan wajib mempertanggungjawabkan perbuatannya sendiri tidak terkecuali dan tidak dapat digantikan oleh siapapun termasuk oleh orang tua. Berdasarkan uraian di atas penulis tertarik untuk mengangkat judul:

"Pemenuhan Hak Anak Sebagai Korban Tindakan Asusila dalam Perspektif HAM di Desa Tenganan Pegringsingan Kecamatan Manggis Kabupaten Karangasem".

\section{METODE PENELITIAN}

Jenis penelitian yang digunakan dalam penelitian ini adalah penelitian hukum empiris, jenis penelitian ini merupakan salah satu cara yang dapat ditempuh untuk mendapatkan kebenaran, yaitu dengan melihat peraturan yang ada dengan pelaksanaannya atau kenyataan dalam masyarakat. Jenis data yang digunakan yaitu menggunakan bahan data primer dan data sekunder yang terdiri dari: Data Primer yang merupakan data yang diperoleh secara langsung dari sumber utama yakni pihak yang menjadi obyek dari penelitian ini. Data primer dalam penelitian ini adalah data yang dihasilkan melalui wawancara secara langsung dengan informan. selanjutnya digunakan Data Sekunder yaitu data yang mendukung data primer, mencakup data lokasi penelitian dan data lain yang mendukung masalah penelitian. Data sekunder diperoleh dari observasi dan literatur yang relevan dengan penelitian yang sedang dilakukan. Selain itu juga, data sekunder bisa diperoleh melalui foto-foto yang berhubungan dengan

4 Moeljatno, 2001, Masalah Penegakan Hukum dan Kebijakan Penanggulangan Kejahatan, PT. Citra Aditya Bakti, Bandung,h.41. 
penelitian. Teknik Pengumpulan Data yang dipergunakan adalah Teknik Wawancara dengan Wawancara (interview) terarah merupakan alat pengumpulan data untuk memperoleh informasi langsung dari responden dan informan teknik ini menggunakan pedoman wawancara. Teknik Dokumentasi adalah mengumpulkan data dengan cara mengalir atau mengambil data-data dari catatan, dokumentasi, administrasi yang sesuai dengan masalah yang diteliti. Setelah semua data telah terkumpul dan dicari kebenarannya, maka data tersebut diolah secara kualitatif. Data kualitatif diungkapkan dalam bentuk kalimat serta uraian-uraian, bahkan dapat berupa cerita pendek. Setelah melalui proses pengolahan data, kemudian data tersebut dianalisis dan disajikan secara deskriptif analisis.

\section{HASIL PENELITIAN DAN PEMBAHASAN}

\section{Pemenuhan Hak-Hak Anak Menurut Undang-Undang Nomor 39 Tahun 1999 Tentang Hak Asasi Manusia.}

Berdasarkan Undang Undang Nomor 39 Tahun 1999, Hak Asasi Manusia adalah: "Seperangkat hak yang melekat pada hakikat keberadaan manusia sebagai makhluk ciptaan Tuhan Yang Maha Esa dan merupakan anugerah-Nya yang wajib dihormati dijunjung tinggi, dan dilindungi oleh negara, hukum, pemerintah, dan setiap orang demi kehormatan serta perlindungan harkat dan martabat manusia."

Kitab Undang-Undang Hukum Pidana (KUHP) yang digunakan di Indonesia, bersumber dari Wetboek van Strafrecht Netherland, maka pembentuk Undang-Undang menggunakan istilah strafbaar feit untuk menyebutkan apa yang kita kenal sebagai tindak pidana. Istilah strafbaar feit, terdiri dari tiga unsur kata, yaitu straf, baar, dan feit. Straf diartikan sebagai pidana dan hukum, baar diartikan sebagai dapat atau boleh, dan feit diartikan sebagai tindak, peristiwa, pelanggaran, dan perbuatan. Jadi istilah strafbaar feit adalah peristiwa yang dapat dipidana atau perbuatan yang dapat dipidana ${ }^{5}$.

Tindakan asusila adalah perilaku yang tidak sesuai dengan aturan norma-norma atau kaidah kesopanan yang berlaku di masyarakat. Penjelasan dalam KUHP buku II tindakan asusila berkaitan dengan kejahatan seksual yang mana kejahatan seksual meliputi

5 Amir llyas, 2012, Asas-asas Hukum Pidana, Rangkang Education, Yogyakarta, h. 19. 
pemerkosaan, penyiksaan seksual, pelecehan seksual dan yang lainnya. Di dalam KUHP perbuatan asusila terhadap anak disebut juga dengan perbuatan cabul. Arti dari kata cabul menurut KBBI adalah keji dan kotor, tidak senonoh (melanggar kesopananan dan kesusilaan) sedangkan arti dari kesusilaan sendiri adalah sikap atau peraturan hidup. Menurut R. Soesilo memberikan penjelasan terhadap perbuatan cabul yaitu segala perbuatan yang melanggar kesusilaan (kesopanan) atau perbuatan keji semuanya itu dalam lingkungan nafsu birahi kelamin ${ }^{6}$.

Berdasarkan Undang-Undang Nomor 11 Tahun 2012 tentang Sistem Peradilan Anak menyatakan bahwa: "Anak yang Menjadi Korban Tindak Pidana yang selanjutnya disebut Anak Korban adalah anak yang belum berumur 18 (delapan belas) tahun yang mengalami penderitaan fisik, mental, dan/atau kerugian ekonomi yang disebabkan oleh tindak pidana."

Semua anak mempunyai hak-hak yang sama dalam suatu negara. Hak Anak adalah bagian dari hak asasi manusia yang wajib dijamin, dilindungi, dan dipenuhi oleh orang tua, keluarga, masyarakat, negara, pemerintah, dan pemerintah daerah. Di setiap negara hak anak telah di atur dalam Undang-Undang dalam hal ini tidak terkecuali di Indonesia seperti yang tertuang dalam Undang-Undang Nomor 39 Tahun 1999 Tentang Hak Asasi Manusia.

Pemenuhan Hak-Hak Anak Sebagai Korban Tindak Pidana

Korban dari suatu tindak pidana yang pada dasarnya adalah pihak yang paling menderita pada suatu tindak pidana tetapi justru tidak mendapatkan perlindungan sebanyak yang diberikan Undang-Undang pada pelaku suatu kejahatan. Perlindungan hukum pada korban kejahatan merupakan bagian dari perlindungan masyarakat, dapat diwujudkan melalui bentuk, misalnya sepeti melalui pemberian kompensasi dan restitusi pada korban, pelayanan medis, dan juga barupa bantuan hukum ${ }^{7}$. Pada prinsipnya perlindungan akan hak-hak seseorang sebagai saksi dan korban telah diakomodasikan dalam KUHAP, tetapi mengingat jenis tindak pidana yang semakin beragam dan menimbulkan efek atau akibat bagi keselamatan jiwa saksi/korban atau keluarganya, pada tahun 2006

${ }^{6}$ R. Soesilo, 1996, Kitab-Kitab Undang Hukum Pidana Serta KomentarKomentar Lengkap Pasal Demi Pasal , Politea, Bogor, hlm.212

7 Didik M Arif Mansur, Elisatris Gultom, 2006, Urgensi Perlindungan Korban Kejahatan Antara Norma dan Realita, Rajawali Pers, Jakarta, h.23 
pemerintah Indonesia mengeluarkan Undang-Undang Nomor 13 Tahun 2006 mengenai Perlindungan Saksi dan Korban. Berdasarkan UndangUndang tersebut kemudian dibentuklah Lembaga Perlindungan Saksi dan Korban (LPSK) yang bertugas dan berwenang untuk memberikan perlindungan dan bantuan kepada saksi dan korban. Lingkup perlindungan oleh LPSK adalah pada semua tahap proses peradilan pidana, agar saksi dan/atau korban merasa aman ketika memberikan keterangan.

Pemenuhan Hak-Hak Anak Sebagai Korban Tindakan Asusila di Desa Tenganan Pegringsingan Kecamatan Manggis Kabupaten Karangasem.

Berdasarkan hasil wawancara dapat dianalisis bahwa berkaitan dengan tindakan asusila yang terjadi telah melanggar hak anak di antaranya hak untuk mendapatkan perlindungan, hak untuk berpartisipasi dan berbaur dengan lingkungan sekitarnya. Secara umum tindakan asusil terhadap anak di bawah umur juga memberikan dampak yang buruk baik dampak emosional maupun dampak fisik bagi anak sebagai korban. Dampak secara emosional diantaranya anak sebagai korban mengalami depresi, stress, goncangan jiwa, rasa takut berhubungan dengan orang lain. Secara fisik dampak yang dirasakan anak sebagai korban penurunan nafsu makan, sulit tidur, sakit kepala, luka ditubuh akibat perkosaan, dan juga mengalami kehamilan yang tidak diinginkan.

Dari dampak yang ditimbulkan tindakan asusila maka perlu adanya perlindungan bagi korban yang harus di tegakan sesuai dengan UndangUndang yang berlaku. Bila dikaitkan dengan tindakan asusila di Desa Tenganan perlindungan terhadap korban tidak diberikan secara maksimal mengingat dalam kasus tersebut anak sebagai korban tetap harus menjalankan sanksi adat yang berlaku di Desa tersebut yang mana bila dikaitkan sangat bertentangan dengan Undang-Undang yang mengatur mengenai perlindungan bagi korban ${ }^{8}$. Dalam permasalahan ini seharusnya anak sebagai korban mendapatkan perlindungan sebagai korban yang layak dan tidak memberatkan dirinya sebagai korban.

Pelanggaran rahasia dagang merupakan pelanggaran dalam bidang bisnis, sehingga dibutuhkan penyelesaian perkara secara cepat, biaya yang murah dan sederhana. Kondisi tersebut menyebabkan penyelesaian

8 Wawancara dengan Kelian Banjar Dinas Desa Tenganan PegringsinganKarangasem 14 November 2019 
sengketa secara non litigasi lebih memenuhi kebutuhan para pebisnis yakni pemilik atau pemegang rahasia dagang, dimana penyelesaian sengketa harus diselesaikan secepat dan sesederhana mungkin. Penyelesaian sengketa secara non litigasi ini juga menjamin privasi dari para pihak yang bersengketa.

\section{KESIMPULAN}

Berdasarkan hasil penelitian pemenuhan hak anak korban tindakan asusila yang terjadi di Desa Tenganan belum sepenuhnya terpenuhi sesuai dengan harapan yang tertuang dalam Undang-Undang. Diantaranya dalam segi perlindungan bagi korban dan juga segi penerapan sanksi yang sesuai bagi pelaku. Sehingga di perlukan peran aktif dari seluruh lapisan masyarakat guna menegakan hak-hak anak diantaranya hak atas perlindungan, hak untuk hidup, mempertahankan hidup dan meningkatkan taraf kehidupannya, kemudian hak untuk dibesarkan, dipelihara, dirawat, dididik, diarahkan, dan dibimbing. Sehingga dari semua upaya penyelesaian yang dilakukan menemukan penyelesaian masalah dengan tidak memberatkan anak sebagai korban.

Adapun saran yang dapat diberikan,Pemerintah agar berperan aktif dalam memberikan edukasi terhadap masyarakat terkait dengan masalah pelindungan dan pemenuhan hak-hak anak dan Dalam pembentukan awigawig agar juga menekankan pada sanksi tegas bagi setiap pelaku kejahatan sehingga lebih memberikan efek jera kedepannya.

\section{DAFTAR PUSTAKA}

Buku:

Bungin, Burhan, H.M, 2015, Metodologi Penelitian Sosial dan Ekonomi Format-Format Kuantitatif dan Kualitatif Untuk Studi Sosiologi, Kebijakan Publik, Komunikasi, Manajemen, dan Pemasaran, Kencana, Jakarta.

Erlinda, 2014, Upaya Peningkatan Anak dari Bahaya Kekerasan, Pelecehandan Eksploitasi, (Komisi Perlindungan Anak Indonesia)

llyas, Amir, 2012, Asas-asas Hukum Pidana, Rangkang Education, Yogyakarta.

Mansur, M. Arief, Dikdik dan Gultom, Elisatri, 1995, Bungai Rampai Viktimisasi,Eresco, Bandung.

M. Tufan B, 2016, Sosiologi Hukum Islam Kajian Empirik Komunitas Sempalan, Deepublish, Yogyakarta.

Moeljatno,2001, Masalah Penegakan Hukum dan Kebijakan 
Penanggulangan Kejahatan, PT. Citra Aditya Bakti, Bandung

Smith, K.M Rhona,dkk., 2008, Hukum Hak Asasi Manusia, PUSHAM,Yogyakarta.

Suratman dan H.Philips Dillah, 2013, Metode Penelitian Hukum, Alfabeta,Bandung.

Soesilo,R 1996, Kitab-Kitab Undang Hukum Pidana Serta KomentarKomentar Lengkap Pasal Demi Pasal, Politea, Bogor.

Wahid, Abdul dan Irfan, Muhammad, 2001, Perlindungan Terhadap Korban Kekerasan (advokasiatas hak asasi perempuan),Rafika Aditama,Bandung.

Wirabudi, Amir, 2010, Terpikat Dobel Ikat: Tenun Gringsing. EVE MAGAZINE Indonesia.

W.J.S. Poerwadarminta,1984, Kamus Umum Bahasa Indonesia, Balai Pustaka, Amirko.

\section{Peraturan Perundang-Undangan}

Kitab Undang-Undang Hukum Pidana

Undang-Undang Nomor 39 Tahun 1999 Tentang Hak Asasi Manusia

Undang-Undang Nomor 13 Tahun 2006 mengenai Perlindungan Saksi dan Korban 